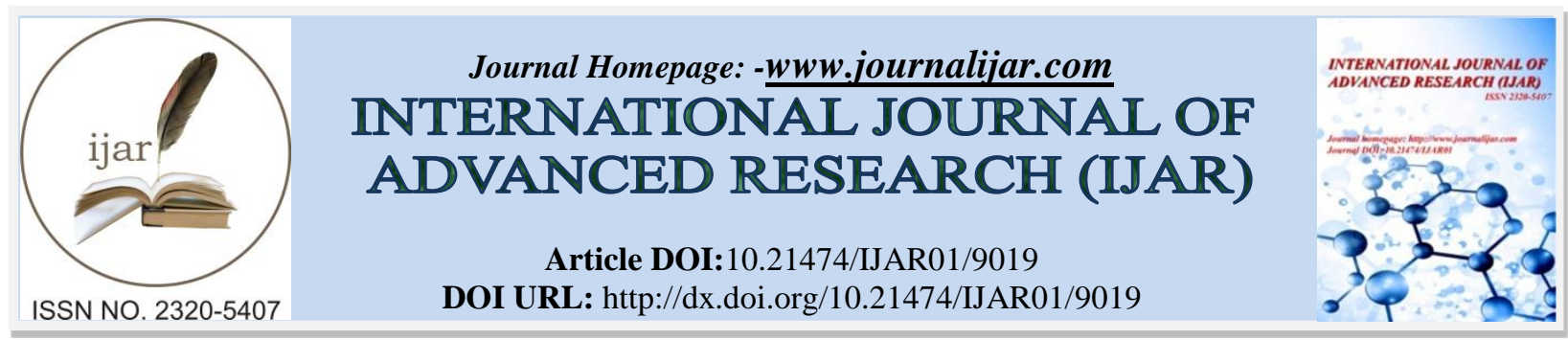

RESEARCH ARTICLE

\title{
CONCEPTUAL REVIEW ON ADHO SHAKHAGATA MARMA.
}

\section{Dr.Prabhjot Kaur Randhawa ${ }^{1}$ and Dr.Pankaj Kumar Rajvanshi ${ }^{2}$.}

1. PG Scholar, Department of Anatomy, Himalayiya Ayurvedic Medical College \& Hospital, Dehradun, Uttrakhand, India.

2. Assistant Professor, Department of Anatomy, Himalayiya Ayurvedic Medical College \& Hospital, Dehradun, Uttrakhand, India.

\section{Manuscript Info}

\section{Manuscript History}

Received: 04 March 2019

Final Accepted: 06 April 2019

Published: May 2019

Key words:-

Marma, Vital points, Sandhisthanam,

Jeevasthanam.

\begin{abstract}
Ayurveda is one such ancient Indian medicine science that represent to the different aspect of medicine. Ayurveda believes that one can be a good physician and surgeon both only when he has practically observed and learned all about the human anatomy. Marma is such a unique principle. It can be explained as sandhisthanam or jeevasthanam. Its first and foremost literature is seen in brihattrayee. However acharya charak described only trimarma (shira, hridaya and basti). Marma are meeting place of five elements of the body namely - Mamsa, Sira, Snayu, Asthi and Sandhi. Marma are the vital areas avoided during surgical procedures due to its fatality. Acharya susruta described 107 marma and According to regional classification he described 44 shakhagata marma-22 urdhva shakhagata and 22 adho shakhagata. Here our attempt is to clarify the concept of adho shakhagata marma.
\end{abstract}

Copy Right, IJAR, 2019,. All rights reserved.

\section{Introduction:-}

Marma are the site where prana or vital energy resides. First and foremost literature of marma is seen in brihattrayee granths which is described in the sixth chapter of susruta samhita sharirasthana pratyekmarmanirdeshsharir, trimarmiyachikitsa chapter in charak samhita, marmavibhaga chapter in ashtanga sangraha, Shariravichayasharira chapter in kashyapa samhita. However acharya charak described only trimarma (shira, hridaya and basti). Marma are those points whose damage cause intense pain simulating death and can cause permanent change in strength and sensation. 'Dalhana' a critic of susruta has cleared this by saying, "Damage to these vulnerable areas may cause death. Vagabhata in his explanation also stated the same i.e. injury to marma may cause death. It consist Agni, Soma, Vayu, Satva, Raja and Tama. If these constituents of the body are disturbed or damaged it is obvious that the man will die or suffer. This also causes the imbalance of doshas (vata, pitta, kapha) and gunas (satva, raja, tama). According to regional classification there are 22 marma in inferior extremity namely- Kshipra, Talahridaya, Kurca, Kurchasiras, Gulpha, Indrabasti, Janu, Ani, Urvi, Lohitaksa, Vitap. ${ }^{1}$

Aim

To explore the Anatomical Manifestation of Adho Shakhagata Marma.

Corresponding Author:-Dr.Prabhjot Kaur Randhawa.

Address:-PG Scholar, Department of Anatomy, Himalayiya Ayurvedic Medical College \& Hospital, Dehradun, Uttrakhand, India. 


\section{Material and Method:-}

Literary and conceptual study will be on the data completions from the bruhatrayees, laghutrayees and other classical books including journals, presented papers, previous work done and co-related, analyzed with the knowledge of contemporary science on the subject. Dissection of marma regions in the dept. of shareera Rachana of Himalayiya Ayurvedic Medical College and Hospital, Dehradun was carried.

\section{Discussion of Adho Shakhagata Marma:-}

\section{MARMA}

The world marma is derived from the Sanskrit root 'MRU'.2

Marma are the centres for the vital force or prana. The concept of marma includes a whole range of anatomical structures like the skin, bones, joints, nerves and internal organs. Susruta in his samhita stated that marma are the vital points there is collection (sannipata) of Mamsa (Muscle), Sira (vessels), Snayu (Tendon), Asthi (Bones) and Sandhi (Joints and nerves). These are the points where 'prana' exist. Which when get injured kills the man ${ }^{3}$.

Marma points consist Agni, Soma, Vayu, Satva, Raja and Tama. If these constituents of the body are disturbed or damaged it is obvious that the man will die or suffer. The dislocation of 'jananendrias' with the subject they are meant for can cause unconsciousness. This also causes the imbalance of doshas (vata, pitta, kapha) and gunas (satva, raja, tama). This may cause the physiological imbalance in the body. Marmas connect to the nadi (subtle nerves) and chakras (energy centres) of the subtle body and the mind. Marmas are primarily energetic centres where the life force accumulates and flows. Significant injury to marmas results in severe and often very special symptoms ${ }^{4}$.

\section{Adho Shakha Gata Marma Kshipra Marma}

This marma is situated between the big toe/thumb and second toe/index finger of the foot/hand. It is 4 in number, 2 in the foot and 2 in the hand. It is $1 / 2$ angula pramana and kalantarapranahara. This marma is predominant of snayu, which is one of the constituent of the marma rachana ${ }^{5}$.

Modern Anatomy of Kshipra Marma-For good understanding of this marma with respect to rachana. There is a need of study of anatomy particularly area between big toe and second toe or thumb and index finger. On the dorsum of the foot following structures are to be considered.

1. Extensor Halluces Longus

2. Extensor Halluces Brevis

3. Dorsalis Pedis Artery

4. Flexor Hellucis Longus

The presence of dorsal pedis artery and the middle terminal branch of the peroneal nerve favours the condition of the tetanus, since the deep wound after hemorrhage favours multiplication in devoid of oxygen. The exotoxins travel through this vasculo nervous tissue and get fixed in the anterior horn cells. Kshipra marma may not be today important from tetanus point of view but from historical background with reference to reorganization of this disease, this marma should be recognized and history should begin from sushruta period ${ }^{6}$.

Effect of Injury-If the injury is in the lower portion of the body, the convulsions can be seen predominantly in the lower portions of the body.

\section{Talahridaya Marma}

Talahridaya marma is situated in the central of the sole of the foot in a straight line drawn from the root of the madhyama anguli (middle toe). It is 4 in number, 2 in upper limb and 2 in lower limb. This marma is predominantly made up of mamsa. It is classified under kalantarapranahara marma. It occupy space of $1 / 2$ angula dimension ${ }^{7}$.

Modern Anatomy of Talahridaya Marma-In the middle of the sole, deep and superficial plantar arches are situated and in palm contemporary deep and superficial palmer arches covered with tendons and plantar and palmer aponeurosis respectively. The lower extremity is more prone from Clostridial myocitis; it is associated with pain, swelling, oedema and toxemia, which usually develops within 48 hours. Toxemia induces adenocrisis causing low 
blood pressure and sudden death. The clostridial infection particularly clostridial welchi produce very painful condition and fatal end is due to shock. This bacterium grows in anaerobic conditions ${ }^{8}$.

Effect of Injury-Injury to this marma leads to severe pain and death or severe pain followed by death, which happens gradually, in due course of time.

\section{Kurcha Marma}

The name of kurcha marma indicates the shape i.e. brush like scattered at one end and tied up on the other end. It is 4 in number. 2 in upper limb and 2 in lower limb. This marma belongs to snayu rachana prakar marma, four angula in measurement and is vaikalyakar in parinam. It is situated above the kshipra marma on both sides ${ }^{9}$.

Modern Anatomy of Kurcha Marma-This is bilaterally situated predominantly constituted by snayu. The probable anatomical structure would be the flexor and extensor tendons coming out of the retinaculae and spread out distally like the open end of brush. It contains tendons on extensor digitorum bravis, extensor digitorum longus, extensor halluces longus, peroneaus tertius ${ }^{10}$.

Effect of Injury-Injury to this marma causes irregular shape, twisting, twitching and tremors and convulsions.

\section{Kurchasira Marma}

It is located distal to the gulpha sandhi in both foot. It is 4 in number, 2 in hands and 2 in foot. Predominantly made up of snayu, 1 angula in measurement and is rujakara in parinam ${ }^{11}$.

Modern Anatomy of Kurchasira Marma-The structures, which are considered as kurchashira at dorsal aspect of foot are tendon of extensor digitorum longus along with peroneus tertius tendon surrounded by a common synovial sheath as they pass beneath the extensor retinacula. As the kurchashira is situated below the gulfa sandhi (ankle joint) only the inferio retinaculum covers the above two tendons, tendons of extensor halluces longus, extensor digitorum brevis along with dorsal metatarsal ligament and cruciate ligaments along with dorsalis pedis artery ${ }^{12}$.

Effect of Injury-Injury to this marma causes severe pain and swelling or edema.

\section{Gulpha Marma}

It is situated at the junction of the foot and the leg. It is 2 in number. It is predominantly made up of sandhi, i.e. the joint and components making ankle joint, 2 angula in measurement and is rujakara in parinam ${ }^{13}$.

Modern Anatomy of Gulpha Marma-The gulpha marma described in Ayurvedic classics at the junction of foot and leg and trauma in this area causes pain, restriction of movement or limping. This description draws the attention towards ankle joints.

Structures falling in the area of gulpha marma are ankle joint, distal tibio-fibular articulation, medial malleolar ligament, anterior ligament, longus ligament, deltoid ligament, posterior ligament, anterior talo-fibular ligament, posterior talo-calcaneal ligament, fibula calcaneal ligament, lateral talo-calcaneal ligament, tarsal articulations ${ }^{14}$.

Effect of Injury-If this marma get injured there can be facture of the concerned bone and dislocation of the joints, and the sprain which can give rise to the trouble stated by sushrut.

\section{Indrabasti Marma}

Indrabasti is situated in between jangha (calf) and parshni (heel) or situated twelve fingers above the heel and at the middle of the jangha (calf). It is 4 in number- 2 in upper limb and 2 in lower limb. It is predominantly made up of mamsa. $1 / 2$ angula in measurement and is kalantarapranahara in parinam ${ }^{15}$.

Modern Anatomy of Indrabasti Marma- The muscle of the calf are present in two groups superficial and deep. Gastrocnemius, planteris and soleus fall under the formar group while the later group contains popleteus, flexor hellusis longus, flexor digitorum longus and tibialis posterior. The calf muscle and the muscle of the sole are enclosed within the deep fascia. The traumatic effect depends on the amount of tissue involved, amount of blood loss. In the single popliteal artery injury, the leg was amputated when disruption occurred due to non-salvageable 
necrosis of muscle. This area also contains the posterior tibial artery and nerve with the vena commitants of the posterior tibial artery ${ }^{16}$.

Effect of Injury-Injury to this area can cause profuse bleeding

\section{Janu Marma}

It is situated at the junction of the 'jangha' and 'uru'i.e. leg and the thigh. It means the knee joint. It is 2 in number. It is predominantly made up of sandhi. 3 angula in measurement and is vaikalyakara in parinam ${ }^{17}$.

\section{Modern Anatomy of janu marma-The knee is the largest joint of the body.}

\section{It actually consists of three joints-}

1. An intermediate patella femoral joint between the patella and the patellar surface of the femur

2. A lateral tibio femoral joint between the lateral condyle of the femur, lateral meniscus and lateral condyle of the tibia.

3. A medial tibiofemoral joint is a gliding joint and the lateral and mediotibiofemoral joints are modified hinge joints.

The anatomical components of the knee joint are Articular capsule, Medial and lateral patellar retinacula, Patellar ligament, Oblique popliteal ligament, Arcuate popliteal ligament, Tibial (Medial) collateral ligament, Fibular (Lateral) collateral ligament, Intracapsular ligament, Articular disc (menisci), Prepatellar bursa, infrapatellar bursa and supra patellar bursa, Common peroneal and tibial nerve, Popliteal artery, Popliteal vein ${ }^{18}$.

Effect of Injury-Injury to knee joint cause's internal dearrangement of the knee joint i.e. injury to semilunar cartilages. Most common are displacement and transverse rupture of the medial semilunar cartilage. The cartilage displaced, may be wedged between the articular surfaces of the bones of the joint, so that the joint is locked.

\section{Ani Marma}

It is situated 3 inches above the knee. It is 4 in number- 2 in upper limb and 2 in lower limb. It is predominantly made up of snayu. $1 / 2$ angula in measurement and is vaikalyakara in parinam ${ }^{19}$.

Modern Anatomy of Ani Marma- The surface anatomy and the rachana of the marma impress upon common tendon of quadriceps muscle in lower extremity. In lower extremity this tendon protects the knee joint from sliding during full flexion. The tone and strength of the muscle is responsible for the stability of the knee joint during various actions $^{20}$.

Effect of Injury- Action of these muscles is affected, the thigh becomes numb and there is stiffness in the thigh, if this marma is injured.

\section{Urvi Marma}

It is situated in the middle of the thigh. It is 2 in number. It is predominantly made up of sira. 1 angula in measurement and is vaikalyakara in parinam $^{21}$.

Modern Anatomy of Urvi Marma- The femoral artery and vein run along the bottom of the femoral triangle along a boundary line that separates two independent motor nerve territories the femoral vein in its upper part lies medial to the femoral artery in the femoral triangle but comes posterior due to intrauterine lateral rotation of the limb and at the apex the relationship between artery and vein is antero posterior; so does, also, the profunda vessels, thus all four vessels are in antero posterior relationship with in the femoral sheath ${ }^{22}$.

Effect of Injury- Injury causes numbness and monoplagia. Only injury to nerves can cause this, no artery or vein can cause this on damage.

\section{Lohitaksha Marma}

It is situated above the urvi and below the hip joint; i.e. at the root of the thigh. It is 4 in number- 2 in upper limb and 2 in lower limb. It is predominantly made up of sira. $1 / 2$ angula in measurement and is vaikalyakara in parinam ${ }^{23}$. 
Modern Anatomy of Lohitaksha Marma- This is the area of the femoral triangle, which contains femoral artery, vein and nerve ${ }^{24}$.

Effect of Injury-If get injured, it can cause loss of blood and monoplegia and wasting of the thigh.

\section{Vitapa Marma}

It is situated at the junction of the thigh and scrotum (Inguinal area). It is 2 in number. It is predominantly made up of snayu. 1 angula in measurement and is vaikalyakara in parinam ${ }^{25}$.

Modern Anatomy of Vitap Marma- This area is of inguinal canal, which contains the spermatic cord, in which there is testicular artery along with the vasa, plexus of veins and nerves of the testes. The corresponding structures in this marma are the contents of superficial inguinal ring. They are ilioinguinal and genitofemoral nerve with spermatic $\operatorname{cord}^{26}$.

Effect of Injury-Injury to this marma causes the necrosis of testes, resulting into impotency and oligozoospermia.

\section{Observation}

Table:-Showing Marma of Lower Extremities

\begin{tabular}{|c|c|c|c|c|c|}
\hline Sr.no & Marma name & No & Ayurvedic menifestation & Modern menifestation & Effect of injury \\
\hline 1. & Talahridaya & 2 & $\begin{array}{l}\text { centre of the sole, facing } \\
\text { the root of the central toe }\end{array}$ & $\begin{array}{l}\text { Plantar aponeurosis in } \\
\text { middle of sole }\end{array}$ & $\begin{array}{l}\text { Its injury leads to } \\
\text { death from severe } \\
\text { pain. }\end{array}$ \\
\hline 2. & Kshipra & 2 & $\begin{array}{l}\text { In between the big toe and } \\
\text { first toe }\end{array}$ & First inter tarsal space & $\begin{array}{ll}\text { Its injury leads } & \text { to } \\
\text { death due } & \text { to } \\
\text { convulsion. } & \end{array}$ \\
\hline 3. & Kurcha & 2 & $\begin{array}{l}\text { Above the kshipra, two } \\
\text { angula ( finger breadth) on } \\
\text { either side }\end{array}$ & $\begin{array}{l}\text { Tarsometatarsal and } \\
\text { Intertarsal ligament }\end{array}$ & $\begin{array}{l}\text { It injury will produce } \\
\text { inability to move and } \\
\text { rotate the foot. }\end{array}$ \\
\hline 4. & Kurchasira & 2 & Just below the ankle joint & $\begin{array}{l}\text { Lateral ligament of } \\
\text { ankle joint }\end{array}$ & $\begin{array}{l}\text { Its injury causes pain } \\
\text { and swelling. }\end{array}$ \\
\hline 5. & Gulpha & 2 & $\begin{array}{l}\text { At the junction of the foot } \\
\text { and the calves }\end{array}$ & Angle joint & $\begin{array}{l}\text { It injury causes pain, } \\
\text { stiffness or loss of } \\
\text { control of the leg and } \\
\text { impotence. }\end{array}$ \\
\hline 6. & Indrabasti & 2 & $\begin{array}{l}\text { In line with the heel, } \\
\text { twelve angula above }\end{array}$ & Calf muscle & $\begin{array}{l}\text { Its injury leads to } \\
\text { death by loss of blood. }\end{array}$ \\
\hline 7. & Janu & 2 & $\begin{array}{l}\text { At the junction of calves } \\
\text { and thighs }\end{array}$ & Knee joint & $\begin{array}{l}\text { Its injury produces } \\
\text { lameness. }\end{array}$ \\
\hline 8. & Ani & 2 & $\begin{array}{l}\text { Three angula above, on } \\
\text { either side of the janu }\end{array}$ & $\begin{array}{l}\text { Tendon of quadriceps } \\
\text { femoris muscle }\end{array}$ & $\begin{array}{l}\text { Its injury causes } \\
\text { increase of swelling } \\
\text { and stiffness or loss of } \\
\text { control of the leg. }\end{array}$ \\
\hline 9. & Urvi & 2 & At the centre of the thigh & Femoral vessels & $\begin{array}{l}\text { Its injury causes } \\
\text { emaciation of the } \\
\text { thigh from loss of } \\
\text { blood. }\end{array}$ \\
\hline 10. & Lohitaksha & 2 & $\begin{array}{l}\text { Above the urvi, below the } \\
\text { angle of the groin and at } \\
\text { the root of the thigh }\end{array}$ & Femoral vessels & $\begin{array}{l}\text { Its injury causes } \\
\text { hemiplegia from loss } \\
\text { of blood. }\end{array}$ \\
\hline 11. & Vitapa & 2 & $\begin{array}{l}\text { In between the groin and } \\
\text { scrotum }\end{array}$ & Inguinal canal & $\begin{array}{lr}\text { Its injury } & \text { causes } \\
\text { impotence } & \text { or } \\
\text { oligospermia } & \end{array}$ \\
\hline
\end{tabular}




\section{Conclusion:-}

After the discussion on adho shakhagata marma. It is concluded that adho shakhagata marma are important marma as clinical and surgical point of view. Injury to them can cause loss of function and sometimes it can also became the cause of death. This study about adho shakhagata marma will be helpful in certain proportion.

\section{References:-}

1. Thatte D.G, editor. A text book of human anatomy. Varanasi: Chawkhamba Sanskrit series office. p-592-593.

2. Radakanta dev. Varda Prasad, editor. Shabdakalpadruma. Vol 5 .ed. Delhi: Naga Publishers;1987. p-792.

3. Thatte D.G, editor. A text book of human anatomy. Varanasi: Chawkhamba Sanskrit series office. p-591.

4. Dr. David frawley, Dr. SubhashRanade and Dr. ArvindLele. Ayurveda and Marma Therapy. Chaukhambha Sanskrit Pratisthan;2005. p-33-34.

5. Dr. Raghuram .Y.S. KshipraMarma: Anatomical location, Effect of injury- Easy Ayurveda (2017/6/6). Retrieved from https://easyayurveda.com>kshi...

6. Mishra J.N,editor . Marma\& its management. Varanasi; Chaukhambhaorientalia; 2005. p-59-62.

7. Dr. Raghuram .Y.S. TalahridayaMarma: Anatomical location, Effect of injury- Easy Ayurveda (2017/6/6). Retrieved from https://easyayurveda.com $>$ talah...

8. Mishra J.N,editor . Marma\& its management. Varanasi; Chaukhambhaorientalia; 2005. p-63-65.

9. Dr. Raghuram .Y.S. KoorchaMarma: Anatomical location, Effect of injury- Easy Ayurveda (2017/6/6). Retrieved from https://easyayurveda.com>koor...

10. Mishra J.N,editor . Marma\& its management. Varanasi; Chaukhambhaorientalia; 2005. p-66,67.

11. Dr. Raghuram .Y.S. KurchashiraMarma: Anatomical location, Effect of injury- Easy Ayurveda (2017/6/6). Retrieved from https://easyayurveda.com>kurc...

12. Mishra J.N,editor . Marma\& its management. Varanasi; Chaukhambhaorientalia; 2005. p-69,70.

13. Dr. Raghuram .Y.S. GulphaMarma: Anatomical location, Effect of injury- Easy Ayurveda (2017/6/6). Retrieved from https://easyayurveda.com>gulp...

14. Mishra J.N,editor . Marma\& its management. Varanasi; Chaukhambhaorientalia; 2005. p-81-83.

15. Dr. Raghuram .Y.S. IndrabastiMarma: Anatomical location, Effect of injury- Easy Ayurveda (2017/6/6). Retrieved from https://easyayurveda.com>indra...

16. Mishra J.N,editor . Marma\& its management. Varanasi; Chaukhambhaorientalia; 2005. p-84-86.

17. Dr. Raghuram .Y.S. jaanuMarma: Anatomical location, Effect of injury- Easy Ayurveda (2017/6/12). Retrieved from https://easyayurveda.com>jaan...

18. Mishra J.N,editor . Marma\& its management. Varanasi; Chaukhambhaorientalia; 2005. p-88-95.

19. Dr. Raghuram .Y.S. AaniMarma: Anatomical location, Effect of injury- Easy Ayurveda (2017/6/7). Retrieved from https://easyayurveda.com>aani...

20. Mishra J.N,editor . Marma\& its management. Varanasi; Chaukhambhaorientalia; 2005. p-103-105.

21. Dr. Raghuram .Y.S. UrviMarma: Anatomical location, Effect of injury- Easy Ayurveda (2017/6/7). Retrieved from https://easyayurveda.com>urvi...

22. Mishra J.N,editor . Marma\& its management. Varanasi; Chaukhambhaorientalia; 2005. p-106-108.

23. Dr. Raghuram .Y.S. LohitakshaMarma: Anatomical location, Effect of injury- Easy Ayurveda (2017/6/7). Retrieved from https://easyayurveda.com>lohit...

24. Mishra J.N,editor . Marma\& its management. Varanasi; Chaukhambhaorientalia; 2005. p-110.

25. Dr. Raghuram .Y.S. VitapaMarma: Anatomical location, Effect of injury- Easy Ayurveda (2017/6/12). Retrieved from https://easyayurveda.com>vitap...

26. Mishra J.N,editor . Marma\& its management. Varanasi; Chaukhambhaorientalia; 2005. p-114. 